\title{
Mutational Analysis of DAX1 in Patients with Hypogonadotropic Hypogonadism or Pubertal Delay*
}

\author{
JOHN C. ACHERMANN, WEN-XIA GU, TOM J. KOTLAR, JOSHUA J. MEEKS, \\ LEAH P. SABACAN, STEPHANIE B. SEMINARA, REEMA L. HABIBY, \\ PETER C. HINDMARSH, DAVID P. BICK, RICHARD J. SHERINS, \\ WILLIAM F. CROWLEY, JR., LAWRENCE C. LAYMAN, AND J. LARRY JAMESON \\ Division of Endocrinology, Metabolism, and Molecular Medicine (J.C.A., W-X.G., T.J.K., J.J.M., \\ L.P.S., R.L.H., J.L.J.), Northwestern University Medical School, Chicago, Illinois 60611; Reproductive \\ Endocrine Unit (S.M.S., W.F.C.), Massachusetts General Hospital, Boston, Massachusetts 02114; \\ London Centre for Paediatric Endocrinology (P.C.H.), University College London, London, United \\ Kingdom W1N 8AA; Genetics and IVF Institute (D.P.B., R.J.S.), Fairfax, Virginia 22031; and Section \\ of Reproductive Endocrinology and Infertility (L.C.L.), University of Chicago, Chicago, Illinois 60637
}

\begin{abstract}
Although delayed puberty is relatively common and often familial, its molecular and pathophysiologic basis is poorly understood. In contrast, the molecular mechanisms underlying some forms of hypogonadotropic hypogonadism (HH) are clearer, following the description of mutations in the genes $K A L, G N R H R$, and PROP1. Mutations in another gene, $D A X 1(A H C)$, cause X-linked adrenal hypoplasia congenita and HH. Affected boys usually present with primary adrenal failure in infancy or childhood and $\mathrm{HH}$ at the expected time of puberty.

DAX1 mutations have also been reported to occur with a wider spectrum of clinical presentations. These cases include female carriers of $D A X 1$ mutations with marked pubertal delay and a male with incomplete $\mathrm{HH}$ and mild adrenal insufficiency in adulthood. Given
\end{abstract}

this emerging phenotypic spectrum of clinical presentation in men and women with $D A X 1$ mutations, we hypothesized that $D A X 1$ might be a candidate gene for mutation in patients with idiopathic sporadic or familial $\mathrm{HH}$ or constitutional delay of puberty. Direct sequencing of $D A X 1$ was performed in 106 patients, including 85 ( 80 men and 5 women) with sporadic $\mathrm{HH}$ or constitutional delay of puberty and patients from 21 kindreds with familial forms of these disorders. No $D A X 1$ mutations were found in these groups of patients, although silent single nucleotide polymorphisms were identified (T114C, G498A). This study suggests that mutations in DAX1 are unlikely to be a common cause of $\mathrm{HH}$ or pubertal delay in the absence of a concomitant history of adrenal insufficiency. ( $J$ Clin Endocrinol Metab 84: 4497-4500, 1999)
$\mathrm{T}$ HE ASSOCIATION of DAX1 (AHC) gene mutations with X-linked adrenal hypoplasia congenita (AHC) and hypogonadotropic hypogonadism $(\mathrm{HH})$ is well established (OMIM: 300200) $(1,2)$. More than 50 different mutations in the gene encoding DAX-1 have been reported in this condition (3-6). Affected boys typically present with primary adrenal insufficiency in infancy or childhood. HH usually becomes evident later in life with failure of pubertal development $(7,8)$.

DAX-1 is an orphan nuclear hormone receptor that is expressed in the adrenal gland, gonads, hypothalamus, and pituitary gonadotropes (9). The $\mathrm{HH}$ caused by DAX1 mutations seems to involve deficits at both hypothalamic and pituitary levels (10-13). DAX-1 is also expressed in Sertoli cells (14), and male Ahch (Dax1) knockout mice have disor-

Received September 3, 1999. Accepted October 12, 1999

Address correspondence and requests for reprints to: J. Larry Jameson, M.D., Ph.D., Endocrinology, Metabolism, and Molecular Medicine, Northwestern University Medical School, 303 East Chicago Avenue, Tarry Building 15-709, Chicago, Illinois 60611.

* This work was performed as part of the National Cooperative Program for Infertility Research and was supported by NIH Grants U54HD-29164 and PO1 HD-21921, and by General Clinical Research Center Grant MO1-RR-00048. J.C.A. received fellowship support from the Special Trustees of the Middlesex Hospital and the Endocrine Fellows Foundation. L.C.L. was supported by National Institute of Child Health and Human Development Grant HD-33004. dered spermatogenesis and infertility (15). DAX-1 has a crucial role, therefore, in the development and function of the reproductive axis at multiple levels. Different approaches to counseling and treatment are needed for patients with DAX1 mutations compared to those with hypothalamic forms of $\mathrm{HH}$, such as Kallmann syndrome $(3,16)$.

Recently, DAX1 gene mutations have been found in several men and women who have less typical reproductive phenotypes. These cases include: 1 ) partial $\mathrm{HH}$ in a man who presented later in life with mild adrenal failure (13); 2) $\mathrm{HH}$, but normal adrenal function, in a woman who is homozygous for a $D A X 1$ mutation through gene conversion (17); and 3) extreme pubertal delay, but normal fertility, among heterozygous female carriers of DAX1 mutations (12). Given the phenotypic spectrum of reproductive disorders now reported, we hypothesized that $D A X 1$ mutations might cause idiopathic familial or sporadic $\mathrm{HH}$ or constitutional delay of puberty (CD) among patients lacking a history of overt adrenal failure. DNA sequence analysis of over 100 such patients suggests, however, that coding sequence mutations in $D A X 1$ are unlikely to be a common cause of such conditions.

\section{Subjects and Methods}

\section{Subjects}

$D A X 1$ was sequenced directly in 106 patients who had sporadic (nonfamilial) or familial HH (see Patient Characteristics for definitions) or 
$\mathrm{CD}$ (testicular volume $<4 \mathrm{~mL}$ and delay of sexual maturation at $14 \mathrm{yr}$ of age). Patients were not recruited if they had multiple pituitary hormone deficiencies or if a likely cause for their altered hypothalamicpituitary-gonadal (HPG) function was evident (for example, a history of tumors, cranial irradiation, or syndromes associated with $\mathrm{HH}$ ). Mutations in the genes encoding the GnRH receptor and anosmin-1 (KAL) had been excluded in $75 \%$ and $80 \%$ of the patients, respectively.

\section{PCR and direct sequencing of DAX1}

After obtaining Institutional Review Board approval, DNA was extracted from patients' blood leukocytes using standard methods. Both exons of DAX1, their splice sites, and a 240-bp 5' region of the DAX1 promoter region were PCR amplified using the following six primer pairs: DAX1.1 For: 5'-TGAGACAGGGAAAGGGGTAAT-3'; DAX1.1 Rev: 5'-CCGGGCTCATCGCCGCACGAA-3'; DAX1.2 For: 5'-TGGTGGATCAGTGTTGGGGC-3'; DAX1.2 Rev: 5'-CCGGGATCAGAGCCGCACGAA-3'; DAX1.3 For: 5'-AAGCAAACGTACGCGGCAC-3'; DAX1.3 Rev: 5'-CCTCTGCGCGAAGTAGGAGC-3'; DAX1.4 For: 5'TAGCTCAAAGCAAACGCACGTG-3'; DAX1.4 Rev: 5'-GACGCCCAGCAGTTGCGCAC-3'; DAX1.5 For: 5'-GCCTCAGCGGGCCTGTTGAAG-3'; DAX1.5 Rev: 5'-CCCGATGCTTTTGTGAGCTGGGAA-3'; DAX2.1 For: 5'-GCTAGCAAAGGACTCTGTGGT-3'; DAX2.1 Rev: 5'-TGTGTGGCCCACATGACTTTA-3'.

PCR conditions were: 1 -min predenaturation at $96 \mathrm{C} ; 35$ cycles of 1 $\min$ at $94 \mathrm{C}$, annealing for $1 \mathrm{~min}$ at $55-58 \mathrm{C}$, and extension for $1 \mathrm{~min}$ at $72 \mathrm{C}$; and 15-min elongation at $72 \mathrm{C}$. Buffer conditions have been described previously (18). Direct sequencing was performed in forward and reverse using dRhodamine (PE Applied Biosystems, Foster City, CA) or Thermo Sequenase II (Amersham Pharmacia Biotech Pharmacia, Piscataway, NJ) dye terminator sequencing kits and automated sequencers (Models 373A and 377; PE Applied Biosystems, Foster City, CA).

\section{Results}

\section{Patient Characteristics}

Patient characteristics are shown in Fig. 1.

Sporadic HH/CD $(n=85)$. The majority of patients investigated had sporadic (nonfamilial) reproductive disorders $(\mathrm{n}=85)$ (Fig. 1, left). Isolated sporadic HH was present in 83 patients (78 men and 5 women), and CD was present in 2

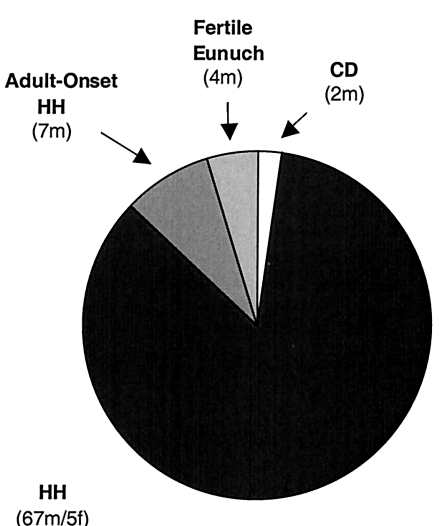

Sporadic $(\mathrm{n}=85)$



Familial $(\mathbf{n}=\mathbf{2 1})$
FIG. 1. Patient characteristics. The majority of patients studied ( $\mathrm{n}=$ 85) had sporadic (nonfamilial) forms of $\mathrm{HH}$ or $\mathrm{CD}$ (left). The remaining patients $(\mathrm{n}=21)$ had familial forms of $\mathrm{HH}$ or $\mathrm{CD}$ (right). A subset of patients who had an X-linked pattern of familial HH or CD were screened first using microsatellite markers in the region of the DAX1 $(A H C)$ locus. Sequencing analysis was only undertaken in those families where two affected brothers inherited a common X-allele from their mother, thus making $D A X 1$ a potential candidate gene for mutation. (m, male; f, female). boys. Of those with $\mathrm{HH}$, seven had an adult-onset form of $\mathrm{HH}$ in which normal pubertal development occurs but $\mathrm{HH}$, apulsatile LH secretion, and low testosterone develops in adult life (19). An additional four men have the fertile eunuch syndrome. This condition is diagnosed when testicular development and spermatogenesis occurs, but systemic testosterone concentrations are insufficient for full virilization (20-22). In the cases of CD, pubertal development was particularly delayed, as no spontaneous testicular enlargement or sexual maturation was evident by 15 yr of age.

Familial $H H / C D(n=21)$. DAX1 was sequenced in a total of 21 kindreds with familial forms of $\mathrm{HH}, \mathrm{CD}$, or both (Fig. 1, right). Families were excluded if the phenotype appeared to be inherited from the proband's father or father's family, as this precluded an X-linked gene as the cause of their condition. A total of 13 of the 21 kindreds had familial $\mathrm{HH}$ affecting both male and female family members. Familial CD with a classic X-linked pattern of inheritance was present in three kindreds. An additional nine families had two affected brothers in the same generation. In these cases, polymorphic microsatellite markers in the region of the DAX1 locus (DXS1202, DXS1214, DXS1226; PE Applied Biosystems) were used first to determine whether both affected sons inherited the same $\mathrm{X}$-chromosome from their mother. Common descent of the same maternal X-allele (DAX1 locus) to both sons occurred in five of the nine families (two $\mathrm{HH} / \mathrm{CD}$, three $\mathrm{CD} / \mathrm{CD}$ ). Because a common allele segregated with the phenotype in these cases, DAX1 was considered a candidate gene, and direct sequencing was undertaken. In four families, however, affected brothers inherited different maternal $\mathrm{X}$-alleles, making $D A X 1$ an unlikely candidate gene for the phenotype seen in these cases (four CD/CD). These families were excluded from further analysis.

\section{Mutational Analysis}

Direct sequencing of the coding region, splice sites, and promoter $(-240 \mathrm{bp})$ of $D A X 1$ did not reveal any mutations in the 106 patients studied. Single nucleotide polymorphisms were detected at two sites [T114C and G498A, the A of the ATG translation initiation codon being designated +1 (23)] (Table 1). These nucleotide changes did not alter the aminoacid sequence of DAX-1 (C38C and R166R, respectively) and were detected at a similar frequency in a control population.

\section{Discussion}

Pubertal delay is a common clinical problem that is multifactorial in its origin. Environmental and nutritional factors can delay the onset and progression of puberty. A variety of hormonal disorders and acquired structural defects that affect the HPG axis can affect the process of sexual maturation (for reviews, see Refs. 24-27). Based on family histories and twin studies, genetic components also seem to contribute to the timing of puberty $(24,28)$. The genetic basis of pubertal development is poorly understood at present. However, the coexistence of pubertal delay with variable degrees of $\mathrm{HH}$ in some families suggests that a common factor may be responsible for these phenotypes in a subset of patients with pubertal disorders (29). 
TABLE 1. Single nucleotide polymorphisms in the coding region of $D A X 1$

\begin{tabular}{|c|c|c|c|c|c|c|}
\hline $\begin{array}{c}\text { Nucleotide } \\
\text { polymorphism }\end{array}$ & Codon & \multicolumn{2}{|c|}{ Males $(\mathrm{n}=95)(\%)$} & \multicolumn{3}{|c|}{ Females $(\mathrm{n}=11)(\%)$} \\
\hline & & $\mathrm{T}$ & C & $\mathrm{TT}$ & $\mathrm{TC}$ & $\mathrm{CC}$ \\
\hline $\mathrm{T} 114 \mathrm{C}$ & C38C & $12(13)$ & $83(87)$ & $3(27)$ & $2(18)$ & $6(55)$ \\
\hline G498A & R166R & $69(73)$ & $26(27)$ & $8(73)$ & $1(9)$ & 2 (18) \\
\hline
\end{tabular}

Several single gene disorders have now been shown to cause $\mathrm{HH}$ in humans (30). Affected patients may show a spectrum of mild to severe phenotypes, even within a kindred with the same mutation. Mutations in these genes may affect the HPG axis at various levels. For example, mutations in $K A L$ (anosmin-1) cause the hypothalamic $\mathrm{HH}$ observed in patients with X-linked Kallmann syndrome $(31,32)$, whereas mutations in the gene encoding the GnRH receptor $(33,34)$ primarily affect gonadotrope function. Mutations in the pituitary transcription factors PROP-1 (35) and HESX-1 (36) can also cause $\mathrm{HH}$, although in these cases additional anterior pituitary hormones are affected. Defining the molecular basis of these reproductive disorders is important because approaches to treatment and counseling are different. At present, however, the underlying pathogenesis of most forms of familial or sporadic $\mathrm{HH} / \mathrm{CD}$ remains unclear $(16,29$, $30,37)$.

The association of $\mathrm{HH}$ with $\mathrm{X}$-linked adrenal hypoplasia congenita and DAX1 gene mutations is well established. Although HPG activity may be relatively preserved in infancy (38-40), the majority of affected patients show marked $\mathrm{HH}$ at the expected time of puberty. In rare cases, partial pubertal development has been observed (5). In this study, we hypothesized that mutations in DAX1 might be found in a subset of patients with $\mathrm{HH}$ or delayed puberty alone. In addition to its functional characteristics, the location of $D A X 1$ on the $\mathrm{X}$ chromosome makes it an attractive candidate gene for a relatively common disorder because phenotypic effects are likely to be manifest in hemizygous males.

We included patients with sporadic as well as familial disorders in our cohort, as over one third of AHC patients reported to date have no other affected family members and they have de novo DAX1 mutations $(4,41,42)$. The recent report of a man who first presented at $28 \mathrm{yr}$ of age with partial $\mathrm{HH}$, but only mild adrenal failure, demonstrates that a reproductive phenotype may precede adrenal symptoms in certain individuals with DAX1 mutations (13). In addition, several females with sporadic $\mathrm{HH}$ were included in this study following the report of a woman with a homozygous $D A X 1$ mutation who has $\mathrm{HH}$ and normal adrenal function (17). Finally, we included families in which both males and females have $\mathrm{HH}$, as extreme pubertal delay has been reported in some female carriers of DAX1 mutations (12). Such a phenotype in heterozygous women could result from skewed X-inactivation.

Identifying patients with DAX1 mutations among those attending clinics for $\mathrm{HH}$ is important for a variety of reasons. First, different approaches to treatment might be needed for such patients, given their variable response to GnRH (10-13). Although data are limited at present, spermatogenesis may be affected by DAX1 mutations in humans as it is in mice (15), and the response to gonadotropin treatment may be im- paired $(12,13)$. Second, these patients may have subclinical adrenal failure that could become clinically significant if left undiagnosed, as highlighted by the patient who presented with increasing symptoms of adrenal insufficiency in his late twenties (13). Third, when the genetic basis for a disorder is identified in a proband, appropriate genetic counseling can be provided to additional family members. In the case of DAX1 mutations, female carriers of the mutation can be advised regarding testing of male offspring for adrenal insufficiency. Boys with DAX1 mutations can be given glucocorticoids and mineralocorticoids, as indicated, and hormonal replacement can be provided at the time of puberty. Finally, any mutations found to be associated with a varied reproductive phenotype could provide important insight into the structure and function of the DAX-1 protein. The majority of $D A X 1$ mutations reported to date are frameshift or nonsense mutations $(3,4)$. Missense mutations, which might cause relatively subtle alterations in protein function, have been rare among the early, classical cases of AHC and seem to be localized to the putative ligand-binding (carboxyterminal) domain of DAX-1 $(1,5,6,38,43-45)$. A direct sequencing approach was used, therefore, to optimize our sensitivity for detecting missense mutations. Although two previously reported polymorphisms were discovered in a significant number of patients (4), no DAX1 mutations were found in the 106 patients studied. These findings indicate that $D A X 1$ mutations are unlikely to be a significant cause of $\mathrm{HH}$ or pubertal delay in the absence of a personal or family history of adrenal failure.

\section{References}

1. Muscatelli F, Strom TM, Walker AP, et al. 1994 Mutations in the DAX-1 gene give rise to both $X$-linked adrenal hypoplasia congenita and hypogonadotropic hypogonadism. Nature. 372:672-676.

2. Zanaria E, Muscatelli F, Bardoni B, et al. 1994 An unusual member of the nuclear hormone receptor superfamily responsible for X-linked adrenal hypoplasia congenita. Nature. 372:635-641.

3. Yu RN, Achermann JC, Ito M, Jameson JL. 1998 The role of DAX-1 in reproduction. Trends Endocrinol Metab. 9:169-175.

4. Reutens AT, Achermann JC, Ito M, et al. 1999 Clinical and functional effects of mutations in the $D A X-1$ gene in patients with adrenal hypoplasia congenita. J Clin Endocrinol Metab. 84:504-511.

5. Bassett JH, O'Halloran DJ, Williams GR, Beardwell CG, Shalet SM, Thakker RV. 1999 Novel DAX1 mutations in X-linked adrenal hypoplasia congenita and hypogonadotrophic hypogonadism. Clin Endocrinol. 50:69-75.

6. Abe S, Nakae J, Yasoshima K, et al. 1999 Novel missense mutation (Leu466Arg) of the DAX1 gene in a patient with X-linked congenital adrenal hypoplasia. Am J Med Genet. 84:87-89.

7. Prader A, Zachmann M, Illig R. 1975 Luteinizing hormone deficiency in hereditary congenital adrenal hypoplasia. J Pediatr. 86:421-422.

8. Golden MP, Lippe BM, Kaplan SA. 1977 Congenital adrenal hypoplasia and hypogonadotropic hypogonadism. Am J Dis Child. 131:1117-1118.

9. Guo W, Burris TP, McCabe ER. 1995 Expression of DAX-1, the gene responsible for X-linked adrenal hypoplasia congenita and hypogonadotropic hypogonadism, in the hypothalamic-pituitary-adrenal/gonadal axis. Biochem Mol Med. 56:8-13.

10. Habiby RL, Boepple P, Nachtigall L, Sluss PM, Crowley Jr WF, Jameson JL. 1996 Adrenal hypoplasia congenita with hypogonadotropic hypogonadism: 
evidence that DAX-1 mutations lead to combined hypothalamic and pituitary defects in gonadotropin production. J Clin Invest. 98:1055-1062.

11. Hamaguchi K, Arikawa M, Yasunaga S, et al. 1998 Novel mutation of the $D A X 1$ gene in a patient with $\mathrm{X}$-linked adrenal hypoplasia congenita and hypogonadotropic hypogonadism. Am J Med Genet. 76:62-66.

12. Seminara SB, Achermann JC, Genel M, Jameson JL, Crowley Jr WF. 1999 X-linked adrenal hypoplasia congenita: a mutation in DAX1 expands the phenotypic spectrum in males and females. J Clin Endocrinol Metab. $84: 4501-4509$.

13. Tabarin A, Achermann JC, Recan D, et al. 1999 A novel mutation in DAX1 gene responsible for late onset adrenal insufficiency, incomplete hypogonadism and impaired spermatogenesis. Proc 81st Meeting of The Endocrine Society, San Diego, CA (Abstract P2-154)

14. Tamai KT, Monaco L, Alastalo TP, Lalli E, Parvinen M, Sassone-Corsi P. 1996 Hormonal and developmental regulation of DAX-1 expression in Sertoli cells. Mol Endocrinol. 10:1561-1569.

15. Yu RN, Ito M, Saunders TL, Camper SA, Jameson JL. 1998 Role of Ahch in gonadal development and gametogenesis. Nat Genet. 20:353-357.

16. Seminara SB, Hayes FJ, Crowley Jr WF. 1998 Gonadotropin-releasing hormone deficiency in the human (idiopathic hypogonadotropic hypogonadism and Kallmann's syndrome): pathophysiological and genetic considerations. Endocr Rev. 19:521-539.

17. Merke DP, Tajima T, Baron J, Cutler Jr GB. 1999 Hypogonadotropic hypogonadism in a female caused by an X-linked recessive mutation in the DAX1 gene. N Engl J Med. 340:1248-1252.

18. Ito M, Mori Y, Oiso Y, Saito H. 1991 A single base substitution in the coding region for neurophysin II associated with familial central diabetes insipidus. J Clin Invest. 87:725-728.

19. Nachtigall LB, Boepple PA, Pralong FP, Crowley Jr WF. 1997 Adult-onset idiopathic hypogonadotropic hypogonadism - a treatable form of male infertility. N Engl J Med. 336:410-415.

20. Pasqualini RQ, Bur EG. 1950 Sindrome hipoandrogenico con gametogenesis conservada: clasificacion de la insuficiencis testicular. Rev Assoc Med Argent. 64:6.

21. McCullagh EP, Beck JC, Scaffenburg CA. 1953 A syndrome of eunuchoidism with spermatogenesis, normal urinary FSH and low or normal ICSH: "Fertile Eunuchs". J Clin Endocrinol Metab. 13:489-509.

22. Boyar RM, Finkelstein JW, Witkin M, Kapen S, Weitzman E, Hellman L. 1973 Studies of endocrine function in "isolated" gonadotropin deficiency. J Clin Endocrinol Metab. 36:64-72.

23. Antonarakis SE. 1998 Recommendations for a nomenclature system for human gene mutations. Nomenclature Working Group. Hum Mutat. 11:1-3.

24. Bourguignon JP. 1996 Environmental factors and human puberty. Acta Paediatr Suppl. 417:92-94.

25. Rogol AD 1998 Leptin and puberty. J Clin Endocrinol Metab. 83:1089-1090.

26. Bradshaw KD, Quigley CA. 1998 Disorders of pubertal development. In: Jameson JL, ed. Principles of molecular medicine. New Jersey: Humana Press; 569-580.

27. Ferin M. 1999 Stress and the reproductive cycle. J Clin Endocrinol Metab. 84:1768-1774.

28. Pickles A, Pickering K, Simonoff E, Silberg J, Meyer J, Maes H. 1998 Genetic "clocks" and "soft" events: a twin model for pubertal development and other recalled sequences of developmental milestones, transitions, or ages at onset. Behav Genet. 28:243-253.
29. Waldstreicher J, Seminara SB, Jameson JL, et al. 1996 The genetic and clinical heterogeneity of gonadotropin-releasing hormone deficiency in the human. J Clin Endocrinol Metab. 81:4388-4395.

30. Achermann JC, Jameson JL. 1999 Fertility and infertility: genetic contributions from the hypothalamic-pituitary-gonadal axis. Mol Endocrinol. 13:812-818.

31. Franco B, Guioli S, Pragliola A, et al. 1991 A gene deleted in Kallmann's syndrome shares homology with neural cell adhesion and axonal path-finding molecules. Nature. 353:529-536.

32. Legouis R, Hardelin JP, Levilliers J, et al. 1991 The candidate gene for the $\mathrm{X}$-linked Kallmann syndrome encodes a protein related to adhesion molecules. Cell. 67:423-435.

33. de Roux N, Young J, Misrahi M, et al. 1997 A family with hypogonadotropic hypogonadism and mutations in the gonadotropin-releasing hormone receptor. N Engl J Med. 337:1597-1602.

34. Layman LC, Cohen DP, Jin M, et al. 1998 Mutations in gonadotropin-releasing hormone receptor gene cause hypogonadotropic hypogonadism. Nat Genet 18:14-15.

35. Wu W, Cogan JD, Pfaffle RW, et al. 1998 Mutations in PROP1 cause familial combined pituitary hormone deficiency. Nat Genet. 18:147-149.

36. Dattani MT, Martinez-Barbera JP, Thomas PQ, et al. 1998 Mutations in the homeobox gene HESX1/Hesx1 associated with septo-optic dysplasia in human and mouse. Nat Genet. 19:125-133.

37. Georgopoulos NA, Pralong FP, Seidman CE, Seidman JG, Crowley Jr WF, Vallejo M. 1997 Genetic heterogeneity evidenced by low incidence of KAL-1 gene mutations in sporadic cases of gonadotropin-releasing hormone deficiency. J Clin Endocrinol Metab. 82:213-217.

38. Takahashi T, Shoji Y, Shoji Y, Haraguchi N, Takahashi I, Takada G. 1997 Active hypothalamic-pituitary-gonadal axis in an infant with X-linked adrenal hypoplasia congenita. J Pediatr. 130:485-488.

39. Kaiserman KB, Nakamoto JM, Geffner ME, McCabe ER. 1998 Minipuberty of infancy and adolescent pubertal function in adrenal hypoplasia congenita. J Pediatr. 133:300-302.

40. Peter M, Viemann M, Partsch CJ, Sippell WG. 1998 Congenital adrenal hypoplasia: clinical spectrum, experience with hormonal diagnosis and report on new point mutations of the DAX-1 gene. J Clin Endocrinol Metab. 83:2666-2674.

41. Yanase T, Takayanagi R, Oba K, Nishi Y, Ohe K, Nawata H. 1996 New mutations of DAX-1 genes in two Japanese patients with X-linked congenital adrenal hypoplasia and hypogonadotropic hypogonadism. J Clin Endocrinol Metab. 81:530-535.

42. Kinoshita E, Yoshimoto M, Motomura K, et al. 1997 DAX-1 gene mutation and deletions in Japanese patients with adrenal hypoplasia congenita and hypogonadotropic hypogonadism. Horm Res. 48:29-34.

43. Nakae J, Abe S, Tajima T, et al. 1997 Three novel mutations and a de novo deletion mutation of the DAX-1 gene in patients with X-linked adrenal hypoplasia congenita. J Clin Endocrinol Metab. 82:3835-3841.

44. Schwartz M, Blichfeldt S, Muller J. 1997 X-linked adrenal hypoplasia in a large Greenlandic family. Detection of a missense mutation (N4401) in the DAX-1 gene; implication for genetic counselling and carrier diagnosis. Hum Genet. 99:83-7.

45. Zhang YH, Guo W, Wagner RL, et al. 1998 DAX1 mutations map to putative structural domains in a deduced three-dimensional model. Am J Hum Genet. 62:855-864. 